\title{
Analisis Kesulitan Siswa Dalam Memecahkan Soal Fisika Smp Pada Materi Usaha Dan Energi
}

\author{
Alamsyah, Jusman Mansyur dan Amiruddin Kade \\ Alamsyah.r.gobel@gmail.com \\ Program Studi Pendidikan Fisika FKIP Universitas Tadulako \\ Jl. Soekarno Hatta Km. 9 Kampus Bumi Tadulako Tondo Palu - Sulawesi Tengah
}

\begin{abstract}
Abstrak-Penelitian ini bertujuan untuk mengetahui kesulitan yang dialami oleh siswa SMP dalam menyelesaikan soal fisika pada materi Usaha dan Energi. Populasi penelitian ini sebanyak 22 siswa dengan anggota sampel berjumlah 6 siswa. Responden terbagi atas tiga kategori berdasarkan kesulitan yang dimiliki oleh siswa yaitu kategori kemampuan tinggi, sedang dan rendah. Metode yang digunakan yaitu kualitatif dengan memberikan tes dan serangkaian wawancara semi terstruktur. Tes yang digunakan berupa tes kesulitan siswa dalam menyelesaikan soal fisika pada materi Usaha dan Energi. Hasil penelitian menunjukkan bahwa siswa mengalami kesulitan pada perhitungan dalam memecahkan masalah, kemudian siswa kesulitan dalam menuliskan rumus sebagian dari siswa salah dalam menuliskan rumus yang akan digunakan dalam pemecahan masalah ini dikarenakan siswa kurang dalam pemahaman konsep soal yang diberikan sehingga salah dalam penulisan rumus, kesulitan ya ng selanjutnya yang dimilki oleh responden ialah kurangnya kemampuan dalam memecahkan masalah sebagian responden tidak bisa melanjutkan untuk pemecahan masalah pada soal dikarenakan kurangnya kemampuan siswa dalam pemecahan masalah.
\end{abstract}

Kata Kunci : Analisis, Kesulitan siswa, Usaha dan Energi

\section{PENDAHULUAN}

Kesulitan belajar di sebabkan oleh dua faktor yaitu faktor internal dan eksternal. Mengatasi kesulitan belajar bukanlah sesuatu yang sederhana, tidak cukup hanya dengan mengetahui taraf kecerdasan dan kemandirian siswa saja, tetapi perlu menyediakan prasarana yang memadai untuk penanganan remediasi. Penyelidikan-penyelidikan yang dapat dilakukan untuk mengetahui kesulitan belajar siswa adalah dengan mengadakan observasi, interview, tes diagnostik, dan memanfaatkan dokumentasi.

Pada proses pembelajaran yang di lakukan, ada hambatan yang dialami oleh guru dan siswa. Salah satu diantaranya adalah kendala yang dihadapi oleh para siswa, yaitu mereka cenderung sulit untuk memecahkan masalah khususnya pada pelajaran fisika. Kesulitan siswa dalam memecahkan masalah fisika karena kurangnya pemahaman dan keterampilan. Mata pelajaran fisika selalu menyuguhkan masalah yang menurut siswa berpikir kritis dan sistematis untuk menyelesaikannya [1].

Menyelesaikan masalah dalam fisika, diperlukan langkah-langkah yang sistematis agar proses penyelesaiannya mudah dan terarah. Pemecahan masalah dapat membantu siswa dalam menyelesaikan kesulitan yang dihadapi oleh siswa dalam menanggapi masalah fisika [2].

sebagian besar siswa disekolah mengalami kesulitan dalam belajar matematika karena kurangnya kemampuan dalam memecahkan masalah [3].

Dengan diketahuinya jenis kesulitan yang dihadapi siswa, maka guru dapat memberikan langkah dengan menggunakan metode pembelajaran yang dapat mengatasi kesulitan belajar siswa yang berdampak pada peningkatan hasil belajar siswa. Sangatlah penting mengetahui kesulitan siswa dalam mengerjakan soal-soal fisika agar guru dapat memberikan langkah dengan menggunakan metode pembelajaran yang dapat mengatasi kesulitan belajar siswa yang berdampak pada peningkatan hasil belajar siswa.

Penelitian-penelitian sebelumnya menunjukan bahwa pemecahan masalah fisika dapat membantu siswa dalam menyelesaikan kesulitan masalah fisika. Peneliti menganggap penting untuk dilakukan kajian atau analisis tentang kesulitan siswa dalam menyelesaikan soal fisika SMP pada materi Usaha dan Energi. Penelitian ini hampir sama dengan penelitian-penelitian yang sebelumnya sama-sama menggunakan pemecahan masalah, namun berbeda pada aspek yang akan diteliti penelitian ini menganalsis kesulitan siswa dalam memecahkan soal fisika SMP pada materi Usaha dan Energi.

\section{METODE PENELITIAN}

Penelitian ini adalah penelitian kualitatif dimana data diperoleh berdasarkan faktafakta yang ada di lapangan. Penelitian ini dilakukan di salah satu sekolah menengah 
pertama di kota Palu yaitu SMP N 20 Palu. Subyek penelitian ini adalah siswa kelas VIIID SMP N 20 Palu tahun ajaran 2016/2017 sebanyak 22 orang yang telah mengikuti pembelajaran fisika pada materi Usaha dan Energi. Pemilihan responden wawancara sebanyak 6 orang dipilih berdasarkan tingkat kesulitan yang dimiliki siswa dengan kategori tinggi, sedang, rendah dapat diperoleh dari hasil tes essay Usaha dan Energi siswa dengan menghitung nilai rata-rata dan standar deviasi. Penelitan ini dilakukan selama 6 bulan dimulai dibulan Maret hingga agustus 2017

Peneliti sebagai instrumen utama akan memberikan beberapa tes kepada responden dan mengambil beberapa responden yang diwawancarai untuk dideskripsikan lebih lanjut. Tes yang digunakan dalam penelitian ini adalah tes kesulitan keulitan siswa dalam memecahkan soal yang berjumlah 5 butir tentang materi Usaha dan Energi.

Jenis wawancara yang digunakan pada penelitian ini adalah wawancara semiterstruktur (Semistructure interview), jenis wawancara ini termasuk kategori in-dept interview dimana pelaksanaanya lebih bebas bila dibandingkan dengan wawancara terstruktur. Tujuan dari wawancara ini adalah untuk menemukan permasalahan secara lebih terbuka, pihak yang diajak wawancara diminta pendapat, dan ideidenya.

\section{HASIL DAN PEMBAHASAN}

Setelah data diperoleh dari sampel penelitian selanjutnya dilakukan analisis terhadap data hasil penelitian tersebut, sehingga memberikan gambaran mengenai permasalahan yang diteliti, untuk itu perlu dilakukan analisis terhadap data hasil penelitian.

1. Kesulitan pada konsep usaha oleh gaya yang berlawanan

Hasil tes kesulitan pada konsep usaha oleh gaya yang berlawanan, dari Gambar 1 dapat dilihat bahwa kesulitan yang dialami siswa ialah tidak memahami konsep Usaha dan Energi oleh gaya yang berlawanan.

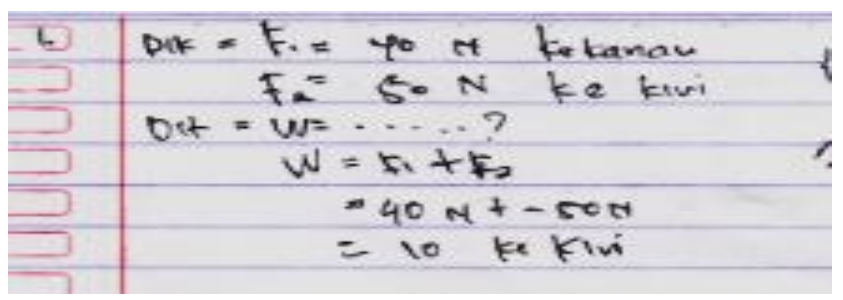

Gbr 1. Kutipan jawaban responden pada konsep usaha oleh Gaya yang berlawanan
Gbr 1 menunjukan bahwa responden tidak menjawab dengan benar pada konsep usaha dengan arah gaya yang berlawanan responden salah dalam menuliskan apa yang diketahui dan ditanyakan seharusnya yang ditanyakan ialah usaha tetapi responden menuliskan perpindahan, kemudian untuk pemecahan masalah responden salah dalam menuliskan rumus hal ini dikarenakan responden tidak memahami konsep pada soal usaha oleh gaya yang berlawanan.

2. Kesulitan pada konsep Energi Kinetik

Kesulitan yang dialami siswa pada konsep energi kinetik ialah, seperti terlihat pada Gambar 2 bahwa siswa tidak dapat melanjutkan ketahap perhitungan pada soal konsep energi kinetik

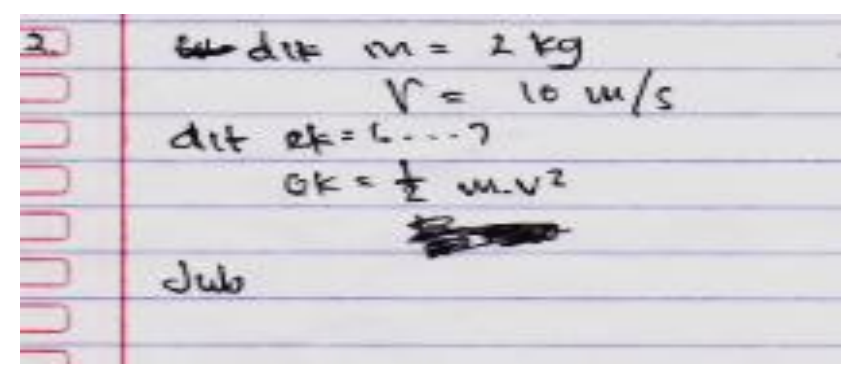

Gbr 2. Kutipan jawaban responden pada konsep Energi Kinetik

Jawaban responden pada Gbr 2 menunjukan bahwa responden dengan benar menuliskan apa yang diketahui dan ditanyakan serta benar menuliskan rumus namun pada tahap pemecahan masalah responden tidak bisa melanjutkan perhitungan pada soal.

3. Kesulitan pada konsep Energi Potensial

Kesulitan yang dialami responden pada konsep energi potensial ialah sebagian responden tidak mengetahui rumus yang akan digunakan dalam menyelesaikan konsep energi potensial sehingga mengakibabtkan kesalahan dalam hasil akhir hal ini dapat kita lihat seperti pada gbr 3.

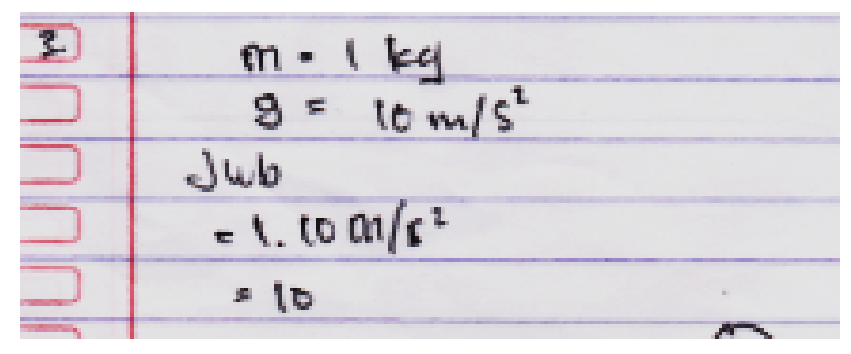

Gbr 3. Kutipan jawaban responden pada konsep Energi Potensial

jawaban pada Gbr 3 menunjukan bahwa responden hanya benar dalam menuliskan apa yang diketahui namun dalam pemecahan 
masalah responden tidak dapat menuliskan rumus yang akan digunakan dalam menyelesaiakan konsep energi potensial sehingga responden salah dalam melakukan perhitungan dan hasil akhir.

4. Kesulitan pada konsep Hubungan Usaha dengan Energi Kinetik

Kesulitan responden pada konsep hubungan usaha dengan energi kinetik ialah sebagian responden salah dalam menafisrkan rumus yang akan digunakan untuk menetukan hubungan usaha dengan energi kinetik, kemudian kesulitan yang lain ialah tidak bisa melanjutkan ketahap pemecahan masalah hal ini dikarenakan responden tidak memahami konsep pada soal sehingga tidak mengetahui rumus yang akan digunakan hal ini dapat dilihat seperti pada Gbr 4.

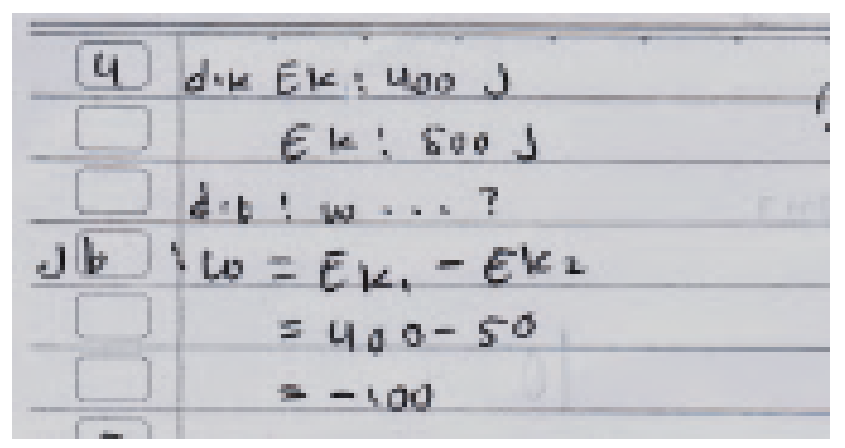

Gbr.4. jawaban responden untuk konsep hubungan usaha dengan energi kinetik

Gbr 4 menunjukan bahwa responden benar menuliskan apa yang diketahui dan ditanyakan namun salah dalam penulisan rumus sehingga mengakibatkan kesalahan dalam perhitungan dan hasil akhir pada soal konsep hubungan usaha dengan energi kinetik.

5. Kesulitan pada konsep Hubungan usaha dengan Energi Potensial

Kesulitan responden pada konsep hubungan usaha dengan energi potensial seperti terlihat pada Gambar 5 ialah responden kesulitan dalam pemecahan masalah diakrenakan responden tidak mengetahui rumus yang akan digunakan dalam menyelesaikan soal hubungan usaha dengan energi potensial. Sebagian dari responden hanya bisa menuliskan apa yang diketahui dan ditanyakan pada soal.

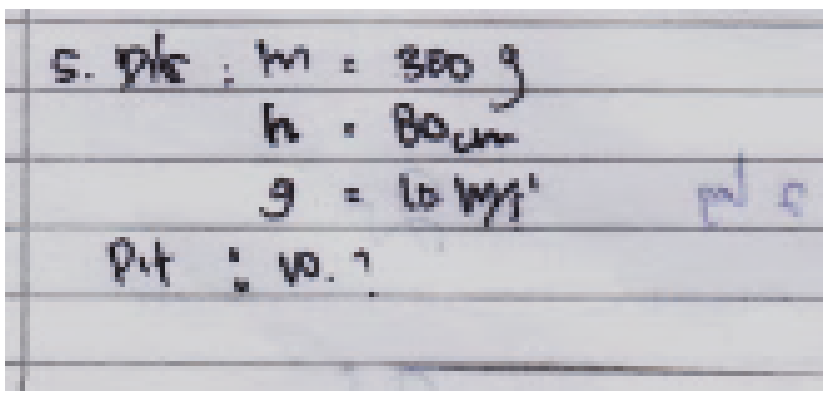

Gbr 5. Kutipan jawaban responden pada konsep hubungan Usaha dengan Energi Potensial

Gbr 5 menunjukan bahwa responden menuliskan dengan benar apa yang diketahui dan ditanyakan namun responden tidak bisa melanjutkan ketahap pemecahan masalah dikarenakan tidak mengetahui rumus yang akan digunakan dalam soal konsep hubungan usaha dengan energi potensial.

Hasil rangkuman kesulitan 22 siswa dari lima konsep menunjukan bahwa paling dominan siswa mengalami kesulitan pada perhitungan dalam memecahkan masalah, hal ini dikarenakan responden lemah dalam kemampuan matematika yang dimiliki sehingga mengakibatkan kesalahan dalam perhitungan untuk pemecahan masalah. Dengan menggunakan pemecahan masalah dan kemampuan matematika, siswa dapat dengan mudah menyelesaikan kesulitan dalam menyelesaikan soal fisika [4].

Kesulitan yang dimiliki oleh responden selanjutnya ialah salah menuliskan rumus sebagian dari responden salah dalam menuliskan rumus yang digunakan dalam pemecahan soal ini dikarenakan siswa tidak mengetahui rumus yang akan digunakan dalam pemecahan masalahnya dan juga salah menafsirkan apa yang ditanyakan dalam soal kedalam bentuk pemecahan masalah sehingga salah menuliskan rumus, sebagian responden tidak memahami konsep dalam pemecahan masalah yang diberikan, yang terakhir ialah 2 dari 22 siswa tidak bisa menjawab soal yang diberikan hal ini disebabkan responden tidak memahami soal. Tiga hambatan utama kesulitan siswa dalam menyelesaikan pemecahan masalah fisika ialah tidak memahami soal, salah menafsirkan soal dan lemahnya kemampuan matematika merupakan hambatan utama dalam pemecahan masalah fisika [5].

Kesulitan yang selanjutnya yang dimiliki responden dalam menyelesaikan permasalahan fisika ialah ialah kurangnya kemampuan dalam memecahkan masalah banyak responden yang tidak bisa melanjutkan ketahap selanjtunya dalam 
permasalahan yang diberikan responden hanya bisa menuliskan apa yang diketahui dan ditanyakan dengan benar namun responden tidak bisa melanjutkan untuk pemecahan masalah pada soal tersebut hal ini diakarenakan kurangnya kemampuan responden dalam pemecahan masalah, sebagian besar siswa disekolah mengalami kesulitan dalam belajar matematika karena kurangnya kemampuan dalam memecahkan masalah [3].

\section{KESIMPULAN}

Berdasarkan hasil analisis tes kesulitan siswa dalam memecahkan masalah fisika pada materi Usaha dan Energi dan wawancara yang diberikan kepada siswa, maka dapat disimpulkan bahwa Pada soal essay Usaha dan Energi sebagian siswa mengalami kesulitan dalam pemecahan masalah pada soal hal ini dikarenakan siswa belum memahami konsep Usaha dan Energi sehingga tidak mengetahui rumus yang akan digunakan dalam pemecahan masalah pada soal, sebagian dari siswa menuliskan rumus yang salah dalam pemecahan masalah pada soal. Dari hasil wawancara banyak siswa yang kebingungan Dengan bentuk soal dan juga siswa tidak mengetahui rumus yang akan digunakan dalam pemecahan masalah pada soal, kemudian kesulitan yang lain ialah banyak siwa yang mengalami kesalahan dalam melakukan perhitungan hal ini dikarenakan siwa masih lemah dalam kemampuan matemetika sehingga mengakibatkan kesalahan dalam melakukan perhitungan.

\section{DAFTAR PUSTAKA}

[1]. Ogunleye. A.O. 2009. Teachers' And Students' Perceptions Of Students' Problem-Solving Difficulties In Physics: Implications For Remediation, Journal of College Teaching \& Learning-November Volume 6, Number 7

[2]. M. Snetinova, Z. Koupilova (2012). Students' Difficulties in Solving Physics Problems. Charles University in Prague, Faculty of Mathematics and Physics, Prague, Czech Republic. WDS'12 Proceedings of Contributed Papers, Part III, 93-97, 2012.

[3]. Nasarudin Abdullah, Lilia Halim \& Effandi Zakaria. (2014). VStops: A Thinking Strategy and Visual Representation Approach in Mathematical Word Problem Solving toward Enhancing STEM Literacy. Eurasia Journal of Mathematics, Science \& Technology Education, 2014, 10(3), 165-174

[4]. N. Johnson (2012). Teacher's And Student's Perceptions Of Problem Solving Difficulties InPhysics. Perunthalaivar Kamarajar College Of EducationKaraikal, U. T Of Puducherry. International Multidisciplinary e-Journal ISSN 2277 - 4262

[5]. Benson SOONGa, Neil MERCERa, Siew Shin Erb (2012) Students' Difficulties When Solving PhysicsProblems: Results from an ICT-infused Revision Intervention. aFaculty of Education, University of Cambridge, United KingdombDepartment of Science, Bartley Secondary School Singapore. 